\title{
Rhodium(III)-Catalyzed Dimerization of Aldehydes to Esters
}

\author{
Cristina Tejel,* Miguel A. Ciriano, and Vincenzo Passarelli
}

In response to the increasing social demand for clean and environmental friendly procedures, recent years have witnessed a dramatic growth in the search for selective chemical processes with $100 \%$ atom economy. Among them, the catalyzed coupling of aldehydes to the corresponding esters (Tishchenko reaction, Scheme 1) is key for the synthesis of these valuable chemicals. ${ }^{[1]}$ This reaction and the related dismutation of aldehydes known as the Cannizzaro reaction typically suffer from the formation of side products, but it represents an attractive alternative to traditional ester syntheses that require, in general, the activation of the free acid through conversion to the acyl chloride or anhydride $^{[2]}$ with the subsequent production of wastes. In this context, a new catalytic approach providing esters by dehydrogenation of alcohols has been recently reported by Milstein. ${ }^{[3]}$

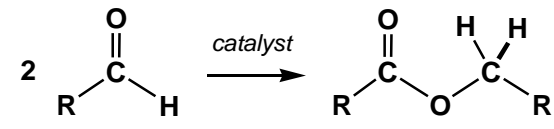

Scheme 1. Dimerization of aldehydes to esters.

A number of homogenous catalysts have been designed and tested for the Tischenko coupling. ${ }^{[1,2,4]}$ Representative catalysts are alkaline ${ }^{[5]}$ and alkaline earth amides ${ }^{[6]}$ aluminum alkoxides, ${ }^{[7]}$ and lanthanide ${ }^{[8]}$ and actinide compounds. ${ }^{[9]}$ Special mention requires a lanthanide formamidinate complex reported by Roesky, ${ }^{[10]}$ for being the most active Tishchenko's catalyst known up to date. Late transition metal complexes have been comparatively quite less studied as catalysts for this reaction. ${ }^{[11]}$ Pioneering works in rhodium chemistry showed that low-valent rhodium(I) hydrides such as $\left.\left[\mathrm{RhH}(\mathrm{CO})\left(\mathrm{PPh}_{3}\right)_{3}\right]^{[}{ }^{12}\right]$ and $\left[\mathrm{RhH}\left(\mathrm{PPh}_{3}\right)_{4}\right]^{[13]}$ catalyze the coupling of aldehydes while better results were achieved using cationic rhodium(I) compounds. ${ }^{[14]}$ Nonetheless, either warming or long reaction times are required to achieve acceptable results and their activity is not comparable to that reported for the Roesky's catalyst. We have recently found that the rhodium scaffold ' $\left(\mathrm{PhBP}_{3}\right) \mathrm{Rh}$ ', bearing the tripodal anionic phosphinoborate ligand $\left[\mathrm{PhB}\left(\mathrm{CH}_{2} \mathrm{PPh}_{2}\right)_{3}\right]^{-}\left(\mathrm{PhBP}_{3}\right)$, is able to stabilize unusual peroxo and hydroperoxo compounds, ${ }^{[15]}$ and shows a good catalytic activity in selective hydrogenation of the carbaldehyde group in $\alpha, \beta$-unsaturated aldehydes. ${ }^{[16]}$ This led us to study the potential of hydrido complexes containing this platform in reactions with carbonyl compounds seeking to find

Dr. C. Tejel, Prof. Dr. M. A. Ciriano, Dr. V. Passarelli

Departamento de Química de Coordinación y Catálisis Homogénea Instituto de Ciencia de Materiales de Aragón (ICMA)

C.S.I.C.-Universidad de Zaragoza,

Pedro Cerbuna 12, 50009-Zaragoza (Spain)

Fax: (+34) 976-761-187

E-mail: ctejel@unizar.es

Supporting information for this article is available on the WWW under http://www.chemeurj.org/ or from the author. details in the reduction to alcohols above mentioned. However, we found instead a disproportionation of aldehydes that traditionally has been promoted by a Lewis acid. Thus, herein we report on the exceptional catalytic activity of a ' $\left(\mathrm{PhBP}_{3}\right)$ ' rhodium(III) complex for the selective dimerization of aromatic and aliphatic aldehydes to esters under remarkably mild conditions, which seems to be related to an unusual mechanism for rhodium catalyzed reactions.

To compare results, reactions of rhodium(I) complexes bearing the ' $\left(\mathrm{PhBP}_{3}\right) \mathrm{Rh}$ ' moiety with benzaldehyde, cynnamaldehyde and cyclohexanecarbaldehyde in a close to stoichiometric ratio were assayed. All the Rh(I) complexes tested produced systematically the decarbonylation of the aldehyde ${ }^{[17]}$ along with the complexes $\left[\left(\mathrm{PhBP}_{3}\right) \mathrm{Rh}(\mathrm{CO})_{2}\right]$ and $\left[\left(\mathrm{PhBP}_{3}\right) \mathrm{Rh}(\mathrm{CO})(\mathrm{H})_{2}\right]$. However, reactions of the $\mathrm{Rh}(\mathrm{III})$ hydrido complex $\left[\left(\mathrm{PhBP}_{3}\right) \mathrm{Rh}(\mathrm{H})_{2}(\mathrm{NCMe})\right](\mathbf{1})^{[16]}$ with benzaldehyde and cyclohexylcarbadehyde gave immediately the corresponding esters from the dimerization of the aldehyde. Preliminary catalytic experiments at room temperature in $\mathrm{C}_{6} \mathrm{D}_{6}(1 \mathrm{~mol} \%$ of $\mathbf{1})$ with benzaldehyde as model showed the reaction to be fully selective to benzylbenzoate by NMR and completed within 10 min with a initial TOF of $2830 \mathrm{~h}^{-1}$, being thus even faster than the Roesky's catalyst. ${ }^{[10]}$ Analysis of the solution after the catalysis indicated the dihydride $1(56 \%)$ along with $\left[\left(\mathrm{PhBP}_{3}\right) \mathrm{Rh}(\mathrm{H})_{2}(\mathrm{CO})\right]^{[16]}(\mathbf{2}$, $12 \%)$ and $\left[\left(\mathrm{PhBP}_{3}\right) \mathrm{Rh}(\mathrm{H})\left(\mathrm{O}_{2} \mathrm{CPh}\right)\right](\mathbf{3}, 31 \%)$ to be the sole rhodium complexes by ${ }^{1} \mathrm{H}$ and ${ }^{31} \mathrm{P}\left\{{ }^{1} \mathrm{H}\right\}$ NMR. The last two complexes, $\mathbf{2}$ and $\mathbf{3}$, were the result of undesirable lateral reactions. They are inactive for the dimerization of benzaldehyde, as verified in separate experiments.

Complex 2 results from aldehyde decarbonylation, probably triggered by rhodium(I) species of the type $\left[\left(\mathrm{PhBP}_{3}\right) \mathrm{Rh}(\mathrm{PhCHO})_{2}\right]$ (Scheme 2) ensuing from hydrogen release (observed by ${ }^{1} \mathrm{H}$ NMR). ${ }^{[18]}$ Complex 3 and hydrogen result from the protonation of $\mathbf{1}$ with benzoic acid, as shown in a separate experiment. Moreover, water produces $\mathbf{3}$ and the alcohol $\mathrm{PhCH}_{2} \mathrm{OH}$ in equimolar amounts (see below). Since water and acids destroy the catalyst, the optimal conditions for the catalytic assays are working-up under anhydrous conditions with freshly distilled aldehydes and saturation of the solution with hydrogen to avoid $\mathrm{Rh}(\mathrm{I})$ species in the reaction medium.

The generality and scope of the reaction under these conditions is summarized in Table 1. The reactions were completed in few min, while the fully selective and quantitative conversion to the esters was observed. The reaction runs with substituted benzaldehydes containing electron-withdrawing groups $\left(\mathrm{CF}_{3}\right.$, entry 1$)$ and with moderate electron-donating groups (Me, entries 3 and 4) with no appreciable effects due to the ortho substitution. The presence of strong electron-donating groups at the para position such as $\mathrm{MeO}$, significantly reduce the conversion rate because of a partial carbonylation of the catalyst, shown for $p$-methoxybenzaldehyde (entry 5 ) and in less extension for $p$-methylbenzaldehyde (entry 3 ). ${ }^{[19]}$ 
Table 1 . Scope of the coupling of aldehydes to esters catalyzed by complex $\mathbf{1}^{[a]}$

\begin{tabular}{|c|c|c|c|c|}
\hline Entry & Substrate & Conversion $^{[\mathrm{b}]}$ & Time (min) & Yield $^{[c]}$ \\
\hline 1 & & $>99$ & 3 & 92 \\
\hline 2 & & $>91$ & 4 & 81 \\
\hline 3 & & $82(90)$ & $3(14)$ & 75 \\
\hline 4 & & $>99$ & 3 & 81 \\
\hline 5 & & $40(55)$ & $3(15)$ & n.a. \\
\hline 6 & & $>99$ & 3 & 91 \\
\hline 7 & & $>99$ & 3 & 88 \\
\hline 8 & & $>99$ & 3 & 85 \\
\hline 9 & $\mathrm{CH}_{3} \mathrm{C}$ & $>99$ & 3 & 68 \\
\hline
\end{tabular}

[a] Conditions: substrate/catalyst mol ratio 100/1, $0.5 \mathrm{~mL} \mathrm{C}_{6} \mathrm{D}_{6}, \mathrm{rt}, \mathrm{H}_{2}$ atmosphere. [b] Determined by ${ }^{1} \mathrm{H}$ NMR spectra (\%). [c] Isolated yield (\%) on a preparative gram-scale in $5 \mathrm{~mL}$ of toluene.

For comparative purposes we have also tested the activity of $\mathbf{1}$ for the coupling of furfural (entry 6), a reaction that has been reported to be difficult. Traditionally, aluminium alkoxides or lanthanide compounds as catalysts require long reaction times to produce acceptable yields while the more active catalyst, calcium oxide in a heterogeneous way, produces quantitatively 2furylmethyl-2-furancarboxylate after $6 \mathrm{~h}$ at $353 \mathrm{~K}^{[20]}$ As shown in Table 1, complex 1 showed an excellent catalytic activity with this difficult substrate. Significantly, complex $\mathbf{1}$ is also effective for the dimerization of enolizable aldehydes containing one, two and three $\alpha$-protons as verified in the reactions with cyclohexanecarbaldehyde and phenylacetaldehyde (entries 7 and 8). Moreover, acetaldehyde (a chemical highly susceptible for aldol condensation) is also converted into ethyl acetate. No special caution was taken to prevent the undesirable aldolic condensation with these substrates, which was not detected. Further, scaling-up the reaction was undertaken and the esters could be isolated on a gram preparative scale with satisfactory to excellent yields (Table 1) with the lost in the isolated yield depending on the volatility of the ester.

Reutilization of the catalyst was also investigated using the model reaction with benzaldehyde. After completion of the first catalytic run, and once confirmed the presence of $\mathbf{1}$, two consecutive additions of benzaldehyde were loaded. The activity slowly decreased in each new catalytic run (see Supporting Information), which was associated to the partial destruction of the catalyst by water contained by the substrate, reaching a maximum TON of 400 in our hands.

Because few catalysts are effective for both aromatic and aliphatic aldehydes, the catalytic activity of $\mathbf{1}$ was assayed with aliphatic aldehydes, which were carefully distilled and dried. The reactions were carried out under argon in a NMR tube with initial aldehyde:catalyst loadings of 100:1 mol. No hydrogen atmosphere is needed for the reactions of aliphatic aldehydes. The results collected in Table 2 show an exceptionally high activity of the catalyst with a full conversion and $100 \%$ selectivity to the ester in around $1 \mathrm{~min}$. No other organics such as condensation, decarbonylation, or hydrogenation products were detected by NMR. Again, analysis of the solutions from the catalytic runs indicated the dihydride $\mathbf{1}$ to be the major rhodium complex along with variable amounts of the carboxylate complex $\left[\left(\mathrm{PhBP}_{3}\right) \mathrm{RhH}\left(\mathrm{O}_{2} \mathrm{CR}\right)\right]$ depending on the amount of acid/water contained by the substrate. Thus, this solution is still active for further catalytic cycles as long as it contains the dihydride complex 1, which is the resting state of the catalyst. Consequently, the solutions could be reutilized indefinitely in the absence of acid or water. Although the reaction is apparently insensitive to steric effects, as shown for isobutanal and isovaleraldehyde (entries 3 and 5), the presence of functional groups in the substrate, particularly donor groups behaving as ligands, such as double $\mathrm{C}=\mathrm{C}$ bonds, may prevent the catalysis. Thus, no conversion to the ester is observed with crotonaldehyde and trans-2-hexen-1-al.

Table 2. Scope of the condensation of aliphatic aldehydes to esters catalyzed by complex $1^{[\mathrm{a}]}$

\begin{tabular}{cccc}
\hline Entry & Substrate & Conversion $^{[\mathrm{b}]}$ & Time $^{(\mathrm{min})}$ \\
\hline 1 & propanal & $>99$ & 1 \\
2 & butanal & $>99$ & 1 \\
3 & isobutanal & $>99$ & 1 \\
4 & valeraldehyde & $>99$ & 1 \\
5 & isovaleraldehyde & $>99$ & 1 \\
6 & hexanal & $>99$ & 1 \\
7 & crotonaldehyde & $<1$ & - \\
8 & trans-2-hexen-1-al & $<1$ & - \\
\hline
\end{tabular}

[a] Conditions: substrate/catalyst mol ratio 100/1, $0.5 \mathrm{~mL} \mathrm{C}_{6} \mathrm{D}_{6}$, rt, argon atmosphere. [b] Determined by ${ }^{1} \mathrm{H}$ NMR spectra (\%).

A most plausible catalytic cycle is shown in Scheme 2. The initial step consists on the replacement of the labile acetonitrile ligand in $\mathbf{1}$ by the aldehyde in excess to give $\mathbf{A}$. Insertion of the $\mathrm{C}=\mathrm{O}$ bond into the $\mathrm{Rh}-\mathrm{H}$ follows to give the coordinatively insaturated hydride-alkoxo intermediate B. Coordination of a second molecule of aldehyde would give the octahedral complex $\mathbf{C}$ in which a migratory insertion of the carbonyl group into the $\mathrm{Rh}$-alkoxide bond renders the hemiacetal-rhodium(III) intermediate D. Insertion of aldehydes into Rh-alkoxo bonds, although rare, has been previously reported. ${ }^{[21]}$ Again, D is coordinatively unsaturated allowing a direct $\beta$-elimination reaction to produce the dihydride rhodium(III) complex $\mathbf{E}$. The cycle is closed with the replacement of the ester by the aldehyde in $\mathbf{E}$ to regenerate A. A similar cycle has been proposed by Roesky $^{[10]}$ and Darses ${ }^{[11 a]}$ for lanthanide and ruthenium catalysts, respectively. It is interesting to remark that no changes of the oxidation state of the metal $[\mathrm{Rh}(\mathrm{I}) / \mathrm{Rh}(\mathrm{III})]$ occur in this catalytic cycle, being all intermediates rhodium(III) compounds. 


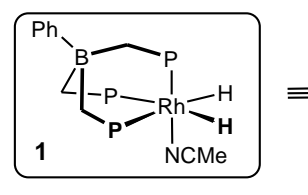<smiles>[R]C([R])OCCPCC</smiles>
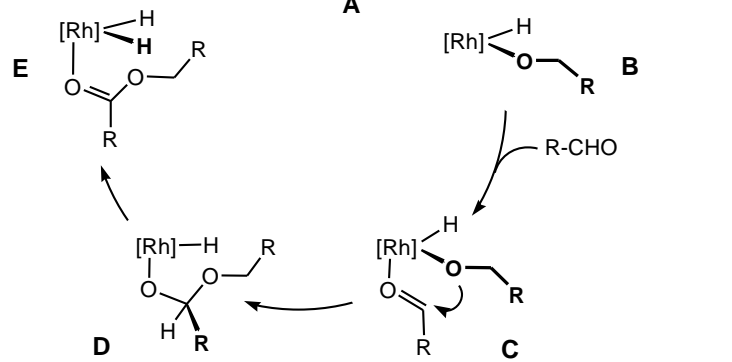

Scheme 2. Proposed mechanism for the dimerization of aldehydes catalyzed by 1 .

Support for the first steps of the cycle comes from the reaction of 1 with 2-pyridylcarbaldehyde. Upon mixing, a fair-yellow solution of the new alkoxy-hydride complex $\left[\left(\mathrm{PhBP}_{3}\right) \mathrm{RhH}\left(\mathrm{OCH}_{2} \mathrm{Py}\right)\right]$ (4, Scheme 3) results. Evidence for the aldehyde insertion into one of the $\mathrm{Rh}-\mathrm{H}$ bonds comes from the new signals at $\delta 5.86 \mathrm{ppm}$ for the $\mathrm{CH}_{2} \mathrm{O}-\mathrm{Rh}$ group, while the remaining hydride appears at $\delta=-6.29 \mathrm{ppm}$ in 4 . Consistent with the proposed structure, complex $\mathbf{4}$ exhibit three inequivalent phosphorus nuclei in the ${ }^{31} \mathrm{P}\left\{{ }^{1} \mathrm{H}\right\}$ NMR spectrum.

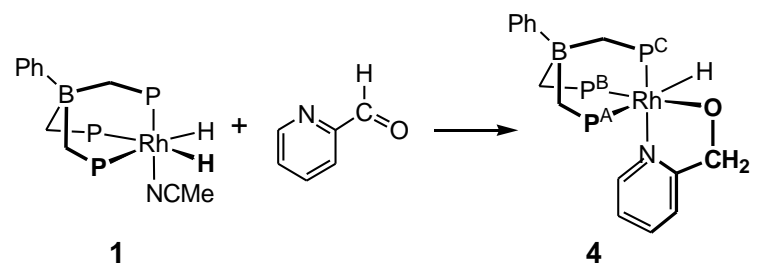

Scheme 3. Reaction of $\mathbf{1}$ with pyridylcarbaldehyde.

Complex $\mathbf{4}$ is inactive for aldehyde dimerization, since it lacks a vacant coordination site for the second molecule of aldehyde. In the same line, donor groups in the substrates or molecules in the reaction medium may become coordinated to the metal in $\mathbf{B}$ avoiding thus the catalysis to proceed. This would account for the lack of catalysis with unsaturated aldehydes (Table 2, entries 7,8) and the adverse action of water. Thus, reactions of $\mathbf{1}$ with benzaldehyde and isobutanal in the presence of added water showed the systematic formation of the alcohol $\mathrm{RCH}_{2} \mathrm{OH}$ and $\left[\left(\mathrm{PhBP}_{3}\right) \mathrm{Rh}(\mathrm{H})\left(\mathrm{O}_{2} \mathrm{CR}\right)\right]$ in equimolar amounts. Almost no catalysis occurred if water/catalyst ratio is $1 / 1$ whereas decreasing the amount of water the catalysis took place, but with variable activity depending on the actual concentration of the catalyst. A reasonable explanation for the action of water is summarized is Scheme 4. Coordination of water in $\mathbf{B}$ promotes the elimination of the alkoxo group as alcohol. Then, insertion of aldehyde into $\mathrm{Rh}-\mathrm{OH}$ followed by a $\beta$-hydrogen elimination and hydrogen evolution would result in the hydride-carboxylate $\left[\left(\mathrm{PhBP}_{3}\right) \mathrm{Rh}(\mathrm{H})\left(\mathrm{O}_{2} \mathrm{CR}\right)\right]$ complexes.

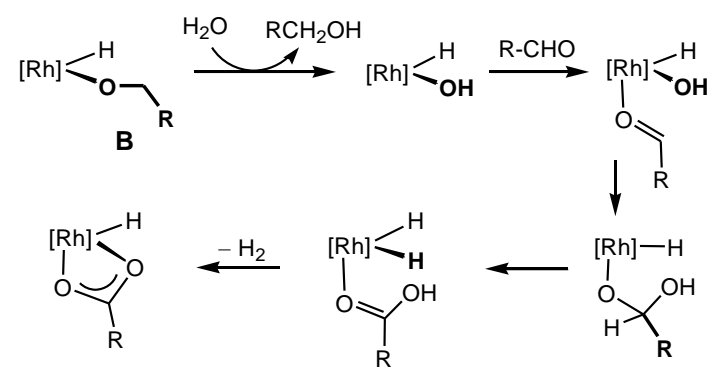

Scheme 4. Adverse action of water in the dimerization of aldehydes.

Preliminary kinetic investigations showed that $1 /[\mathrm{PhCHO}]$ is linearly related to the reaction time, in accordance with a secondorder reaction rate relative to the aldehyde (see Supporting Information). This kinetics would also be compatible with a $\mathrm{Rh}(\mathrm{I}) / \mathrm{Rh}(\mathrm{III})$ catalytic cycle generated by active rhodium(I) species resulting from the reductive elimination of the alcohol from $\mathbf{B}$ or $\mathbf{C}$. This alternative cycle would be similar to the proposed for hydroacylations of $\mathrm{C}=\mathrm{O}$ bonds. ${ }^{[22]}$ However, this possibility is quite unlikely in our case, since i) the dihydride $\mathbf{1}$ is found in the solutions after the catalytic runs even in the absence of hydrogen, ii) isolated rhodium(I) complexes with the ' $\left(\mathrm{PhBP}_{3}\right) \mathrm{Rh}$ ' scaffold and labile ligands produce systematically the aldehyde decarbonilation reaction, and iii) hydrogenation of the $\mathrm{C}=\mathrm{O}$ bond requires high pressure of hydrogen. ${ }^{[16]}$

In summary, we disclose that a dihydridorhodium(III) complex $\left[\left(\mathrm{PhBP}_{3}\right) \mathrm{Rh}(\mathrm{H})_{2}(\mathrm{NCMe})\right]$ is an extremely efficient catalyst for the dimerization of both, aliphatic and aromatic, enolizable and non-enolizable aldehydes under exceptionally smooth conditions. Its exceptional activity likely results from an operative way in which the insertion of the carbaldehyde group into the $\mathrm{Rh}-\mathrm{H}$ bond to give an alkoxo group, and insertion of a second aldehyde into the resulting rhodium alkoxide seems to be essential steps for the dismutation of aldehydes. Most probably, the excellent effectiveness of the lanthanide catalyst and complex 1 could be due to common distinctive steps in spite of the divergent nature of the metals.

\section{Experimental Section}

NMR-scale experiments: A NMR tube was charged with the catalyst, $\left[\left(\mathrm{PhBP}_{3}\right) \mathrm{Rh}(\mathrm{H})_{2}(\mathrm{NCMe})\right](\mathbf{1})(5.0 \mathrm{mg}, 0.006 \mathrm{mmol})$ and dried $\mathrm{C}_{6} \mathrm{D}_{6}(0.4 \mathrm{~mL})$ under argon. For the aldehydes in Table 1, the argon atmosphere was replaced by hydrogen through 3 freeze-thaw cycles and then, dry and freshly distilled aldehyde was added (in a 100/1 mol ratio vs. catalyst). The tube was introduced into the NMR probe and the mixture was analyzed by ${ }^{1} \mathrm{H}$ and ${ }^{31} \mathrm{P}\left\{{ }^{1} \mathrm{H}\right\}$ NMR spectroscopy obtaining the proton spectrum in 2-3 min after mixing. For the aliphatic aldehydes of Table 2 no hydrogen was introduced into the NMR tube and the first proton spectrum was obtained in about $1 \mathrm{~min}$ after mixing. Clean and quantitative conversions to the Tishchenko esters were observed in all the cases except for $p$-methoxy-benzaldehyde $(55 \%)$ and for the unsaturated aldehydes of Table 2 .

Preparative-scale experiments: Only the preparation and isolation of benzyl benzoate is reported in detail. Procedures for other aldehydes were similar, except for acetyl acetate (see below). A toluene solution $(8 \mathrm{~mL})$ of $\left[\left(\mathrm{PhBP}_{3}\right) \mathrm{Rh}(\mathrm{H})_{2}(\mathrm{NCMe})\right](\mathbf{1})$ $(80.0 \mathrm{mg}, 0.096 \mathrm{mmol})$ was saturated with hydrogen $(1 \mathrm{~atm})(3$ freeze-thaw cycles) and then benzaldehyde $(0.98 \mathrm{~mL}, 9.6 \mathrm{mmol})$ was added. After stirring for $10 \mathrm{~min}$ the solution was analyzed by GC-MS, observing the quantitative formation of benzylbenzoate. The solution was evaporated under vacuum and the residue extracted with hexane $(2 \times 5 \mathrm{~mL})$. The extract was chromatographied on a $\mathrm{SiO}_{2}$ column affording a colorless solution, which was evaporated up to dryness affording benzyl benzoate as a colorless viscous liquid. Yield $0.83 \mathrm{~g}(81 \%) .{ }^{1} \mathrm{H}$ NMR (500 $\left.\mathrm{MHz}, \mathrm{CDCl}_{3}, 25^{\circ} \mathrm{C}\right): \delta=8.18(\mathrm{~m}, 2 \mathrm{H}), 7.60(\mathrm{~m}, 1 \mathrm{H}), 7.55-7.38(7 \mathrm{H}), 5.45(\mathrm{~s}, 2 \mathrm{H})$; ${ }^{13} \mathrm{C}\left\{{ }^{1} \mathrm{H}\right\}$ NMR $\left(500 \mathrm{MHz}, \mathrm{CDCl}_{3}, 25^{\circ} \mathrm{C}\right): \delta=166.4\left(\mathrm{CO}_{2}\right), 136.2,133.1,129.8$, 
$128.7,128.5,128.3,128.3,66.75\left(\mathrm{CH}_{2}\right)$. For ethyl acetate: after finished the catalysis, hexane $(10 \mathrm{~mL})$ was added to precipitate the catalyst and the suspension was filtered over a silica gel column affording a colorless solution, which was fractionally distilled to afford acetyl acetate. Yield $0.45 \mathrm{~g}(68 \%) .{ }^{1} \mathrm{H}$ NMR $\left(500 \mathrm{Mhz}, \mathrm{CDCl}_{3}\right.$, $\left.25^{\circ} \mathrm{C}\right): \delta=4.02(\mathrm{qt}, J(\mathrm{H}, \mathrm{H})=6.8 \mathrm{~Hz}, 2 \mathrm{H}), 1.94(\mathrm{~s}, 3 \mathrm{H}), 1.16(\mathrm{t}, J(\mathrm{H}, \mathrm{H})=6.8 \mathrm{~Hz}$, $3 \mathrm{H}) .{ }^{13} \mathrm{C}\left\{{ }^{1} \mathrm{H}\right\}$ NMR $\left(500 \mathrm{MHz}, \mathrm{CDCl}_{3}, 25^{\circ} \mathrm{C}\right): \delta=170.8\left(\mathrm{CO}_{2}\right), 60.2\left(\mathrm{CH}_{2}\right), 20.8$ $\left(\mathrm{CH}_{3}\right), 14.0\left(\mathrm{CH}_{3}\right)$

[(PhBP $\left.\left.{ }_{3}\right) \mathbf{R h}(\mathbf{H})\left(\mathbf{O}_{2} \mathbf{C P h}\right)\right](3)$ : Solid $\mathrm{PhCO}_{2} \mathrm{H}(12.2 \mathrm{mg}, 0.10 \mathrm{mmol})$ was added to a toluene solution $(5 \mathrm{~mL})$ of $\left[\left(\mathrm{PhBP}_{3}\right) \mathrm{Rh}(\mathrm{H})_{2}(\mathrm{NCMe})\right](\mathbf{1})(83.1 \mathrm{mg}, 0.10 \mathrm{mmol})$. After stirring for $15 \mathrm{~min}$, the solution was evaporated to $c a .3 \mathrm{~mL}$, layered with hexane (15 $\mathrm{mL}$ ) and left to stand for two days. The white-off solid that precipitated was washed with hexane and vacuum-dried. Yield: $73.7 \mathrm{mg}(81 \%)$; ${ }^{1} \mathrm{H}$ NMR $\left(500 \mathrm{MHz}, \mathrm{C}_{6} \mathrm{D}_{6}\right.$, $\left.25^{\circ} \mathrm{C}\right) \delta=8.33\left(\mathrm{~d},{ }^{3} J(\mathrm{H}, \mathrm{H})=7.2,2 \mathrm{H}, \mathrm{H}^{\circ}\right)$ and $7.12\left(\mathrm{~m}, 3 \mathrm{H}, \mathrm{H}^{m+p}\right)(\mathrm{PhCOO}), 8.07(\mathrm{~d}$, $\left.{ }^{3} J(\mathrm{H}, \mathrm{H})=7.1 \mathrm{~Hz}, 2 \mathrm{H}, \mathrm{H}^{o}-\mathrm{PhB}\right), 7.88\left(\mathrm{~m}, 4 \mathrm{H}, \mathrm{H}^{o}-\mathrm{Ph}_{2} \mathrm{P}^{\mathrm{A}}\right), 7.69\left(\mathrm{~m}, 6 \mathrm{H}, \mathrm{H}^{o}-\mathrm{Ph}_{2} \mathrm{P}^{\mathrm{A}}\right.$ and $\left.\mathrm{H}^{m}-\mathrm{PhB}\right), 7.45\left(\mathrm{t},{ }^{3} J(\mathrm{H}, \mathrm{H})=7.2 \mathrm{~Hz}, 1 \mathrm{H}, \mathrm{H}^{p}-\mathrm{PhB}\right), 7.34\left(\mathrm{t},{ }^{3} J(\mathrm{H}, \mathrm{H})={ }^{3} J(\mathrm{H}, \mathrm{P})=8.7 \mathrm{~Hz}\right.$ $\left.4 \mathrm{H}, \mathrm{H}^{o}-\mathrm{Ph}_{2} \mathrm{P}^{\mathrm{B}}\right), 6.95\left(\mathrm{br}, 6 \mathrm{H}, \mathrm{H}^{m+p}-\mathrm{Ph}_{2} \mathrm{P}^{\mathrm{A}}\right), 6.82\left(\mathrm{t},{ }^{3} J(\mathrm{H}, \mathrm{H})=7.3 \mathrm{~Hz}, 2 \mathrm{H}, \mathrm{H}^{p}-\mathrm{Ph}_{2} \mathrm{P}^{\mathrm{B}}\right)$, $6.70\left(\mathrm{t},{ }^{3} J(\mathrm{H}, \mathrm{H})=7.1 \mathrm{~Hz}, 6 \mathrm{H}, \mathrm{H}^{m}-\mathrm{Ph}_{2} \mathrm{P}^{\mathrm{B}}\right.$ and $\left.\mathrm{H}^{p}-\mathrm{Ph}_{2} \mathrm{P}^{\mathrm{A}}\right), 6.64\left(\mathrm{t},{ }^{3} J(\mathrm{H}, \mathrm{H})=7.3 \mathrm{~Hz}\right.$, $\left.4 \mathrm{H}, \mathrm{H}^{m}-\mathrm{Ph}_{2} \mathrm{P}^{\mathrm{A}}\right), 1.79\left(\mathrm{~d},{ }^{2} J(\mathrm{H}, \mathrm{P})=11.2 \mathrm{~Hz}, 2 \mathrm{H}, \mathrm{CH}_{2}-\mathrm{P}^{\mathrm{B}}\right), 1.72\left(\mathrm{~m}, 4 \mathrm{H}, \mathrm{CH}_{2}-\mathrm{P}^{\mathrm{A}}\right),-$ $4.92\left(\mathrm{ddd},{ }^{2} J\left(\mathrm{H}, \mathrm{P}^{\mathrm{B}}\right)=197.9, J(\mathrm{H}, \mathrm{Rh})=18.4\right.$ and $\left.{ }^{2} J\left(\mathrm{H}, \mathrm{P}^{\mathrm{A}}\right)=8.2 \mathrm{~Hz}, 1 \mathrm{H}, \mathrm{Rh}-\mathrm{H}\right)$; ${ }^{31} \mathrm{P}\left\{{ }^{1} \mathrm{H}\right\}$ NMR $\left(500 \mathrm{MHz}, \mathrm{C}_{6} \mathrm{D}_{6}, 25^{\circ} \mathrm{C}\right) \delta=52.5(\mathrm{dd}, J(\mathrm{P}, \mathrm{Rh})=123$ and $J(\mathrm{P}, \mathrm{P})=20$ $\left.\mathrm{Hz}, 2 \mathrm{P}, \mathrm{P}^{\mathrm{A}}\right), 7.46\left(\mathrm{dt}, J(\mathrm{P}, \mathrm{Rh})=74\right.$ and $\left.J(\mathrm{P}, \mathrm{P})=20 \mathrm{~Hz}, 1 \mathrm{P}, \mathrm{P}^{\mathrm{B}}\right) ;{ }^{13} \mathrm{C}\left\{{ }^{1} \mathrm{H}\right\} \mathrm{NMR}(500$ $\left.\mathrm{MHz}, \mathrm{C}_{6} \mathrm{D}_{6}, 25^{\circ} \mathrm{C}\right) \delta=179.8\left(\mathrm{CO}_{2}\right), 128.9\left(\mathrm{C}^{o}\right), 131.7\left(\mathrm{C}^{m}\right)$ and $128.0\left(\mathrm{C}^{p}\right)\left(\mathrm{PhCO}_{2}\right)$; elemental analysis calcd (\%) for $\mathrm{C}_{52} \mathrm{H}_{47} \mathrm{BO}_{2} \mathrm{P}_{3} \mathrm{Rh}$ : C 68.59, $\mathrm{H}$ 5.20; found: $\mathrm{C} 68.49$, H 5.38

$\left[\left(\mathbf{P h B P}_{3}\right) \mathbf{R h}(\mathbf{H})\left(\mathbf{O C H}_{2} \mathbf{P y}\right)\right](\mathbf{4})$. Neat PyCHO $(6.8 \mathrm{uL}, 0.072 \mathrm{mmol})$ was added to a suspension of $\left[\left(\mathrm{PhBP}_{3}\right) \mathrm{Rh}(\mathrm{H})_{2}(\mathrm{NCMe})\right](\mathbf{1})(60 \mathrm{mg}, 0.072 \mathrm{mmol})$ in toluene $(3 \mathrm{~mL})$ to give a yellow solution immediately. This was carefully layered with pentane (12 $\mathrm{mL}$ ) to produce pale-yellow microcrystals in two days. The mother liquor was decanted and the solid was washed with $2 \times 2 \mathrm{~mL}$ of pentane and vacuum-dried. Yield: $50 \mathrm{mg}(77 \%) ;{ }^{1} \mathrm{H}$ NMR $\left(300 \mathrm{MHz}, \mathrm{C}_{6} \mathrm{D}_{6}, 25^{\circ} \mathrm{C}\right) \delta=8.44\left(\mathrm{~m}, 2 \mathrm{H}, \mathrm{H}^{o}-\mathrm{PhP}^{\mathrm{C}}\right)$, $8.25\left(\mathrm{~d},{ }^{3} J(\mathrm{H}, \mathrm{H})=7.0 \mathrm{~Hz}, 2 \mathrm{H}, \mathrm{H}^{o}-\mathrm{PhB}\right), 8.15\left(\mathrm{~m}, 4 \mathrm{H}, \mathrm{H}^{o}-\mathrm{PhP}^{\mathrm{C}}+\mathrm{H}^{o}-\mathrm{PhP}^{\mathrm{A}}\right), 8.00(\mathrm{dd}$, $\left.{ }^{3} J(\mathrm{H}, \mathrm{P})=11.2 \mathrm{~Hz},{ }^{3} J(\mathrm{H}, \mathrm{H})=7.4 \mathrm{~Hz}, 2 \mathrm{H}, \mathrm{H}^{o}-\mathrm{PhP}^{\mathrm{B}}\right), 7.73\left(\mathrm{t},{ }^{3} J(\mathrm{H}, \mathrm{H})=7.5 \mathrm{~Hz}, 2 \mathrm{H}\right.$, $\left.\mathrm{H}^{m}-\mathrm{PhB}\right), 7.47\left(\mathrm{t},{ }^{3} J(\mathrm{H}, \mathrm{H})=7.5 \mathrm{~Hz}, 1 \mathrm{H}, \mathrm{H}^{p}-\mathrm{PhB}\right), 7.29\left(\mathrm{dd},{ }^{3} J(\mathrm{H}, \mathrm{P})=8.4 \mathrm{~Hz}\right.$, $\left.{ }^{3} J(\mathrm{H}, \mathrm{H})=7.2 \mathrm{~Hz}, 2 \mathrm{H}, \mathrm{H}^{o}-\mathrm{PhP}^{\mathrm{A}}\right), 7.03(\mathrm{~m}, 6 \mathrm{H}, \mathrm{PhP}), 6.55-6.93\left(\mathrm{~m}, 16 \mathrm{H}, \mathrm{PhP}+\mathrm{H}^{3}\right.$ and $\left.\mathrm{H}^{4} \mathrm{Py}\right), 5.86\left(\mathrm{br} \mathrm{d},{ }^{3} J(\mathrm{H}, \mathrm{P})=5.9 \mathrm{~Hz}, 2 \mathrm{H} \mathrm{Rh}-\mathrm{OCH}_{2}\right), 5.69\left(\mathrm{td},{ }^{3} J(\mathrm{H}, \mathrm{H})=5.9 \mathrm{~Hz}\right.$, $\left.{ }^{4} J(\mathrm{H}, \mathrm{H})=2.0 \mathrm{~Hz}, 1 \mathrm{H}, \mathrm{H}^{5} \mathrm{Py}\right), 5.60\left(\mathrm{~m}, 1 \mathrm{H}, \mathrm{H}^{6} \mathrm{Py}\right), 2.38\left(\delta_{\mathrm{A}}, \mathrm{t},{ }^{2} J(\mathrm{H}, \mathrm{P})=15.7 \mathrm{~Hz}\right.$, $1 \mathrm{H})$ and $1.75\left(\delta_{\mathrm{B}}, \mathrm{m}, J(\mathrm{~A}, \mathrm{~B})=15.1 \mathrm{~Hz}, 1 \mathrm{H}, \mathrm{CH}_{2}-\mathrm{P}^{\mathrm{A}}\right), 2.19\left(\mathrm{~m}, 2 \mathrm{H}, \mathrm{CH}_{2}-\mathrm{P}^{\mathrm{B}}\right), 1.96\left(\delta_{\mathrm{A}}\right.$, $\mathrm{m}, 1 \mathrm{H})$ and $1.31\left(\delta_{\mathrm{B}}, \mathrm{m}, J(\mathrm{~A}, \mathrm{~B})=15.1 \mathrm{~Hz}, 1 \mathrm{H}, \mathrm{CH}_{2}-\mathrm{P}^{\mathrm{C}}\right),-6.29\left(\mathrm{~m},{ }^{2} J\left(\mathrm{H}, \mathrm{P}^{\mathrm{A}}\right)=195.0\right.$ $\left.\mathrm{Hz},{ }^{2} J\left(\mathrm{H}, \mathrm{P}^{\mathrm{B}}\right)=24.2 \mathrm{~Hz},{ }^{2} J\left(\mathrm{H}, \mathrm{P}^{\mathrm{C}}\right)=9.3 \mathrm{~Hz}, J(\mathrm{H}, \mathrm{Rh})=15.2 \mathrm{~Hz}, 1 \mathrm{H}, \mathrm{H}-\mathrm{Rh}\right) ;{ }^{31} \mathrm{P}\left\{{ }^{1} \mathrm{H}\right\}$ $\operatorname{NMR}\left(300 \mathrm{MHz}, \mathrm{C}_{6} \mathrm{D}_{6}, 25^{\circ} \mathrm{C}\right) \delta=45.2(\mathrm{ddd}, J(\mathrm{P}, \mathrm{Rh})=108 \mathrm{~Hz}, J(\mathrm{P}, \mathrm{P})=42$ and 15 $\left.\mathrm{Hz}, \mathrm{P}^{\mathrm{B}}\right), 30.7\left(\mathrm{ddd}, J(\mathrm{P}, \mathrm{Rh})=115 \mathrm{~Hz}, J(\mathrm{P}, \mathrm{P})=42\right.$ and $\left.33 \mathrm{~Hz}, \mathrm{P}^{\mathrm{C}}\right),-2.1(\mathrm{ddd}, J(\mathrm{P}, \mathrm{Rh})$ $=70 \mathrm{~Hz}, J(\mathrm{P}, \mathrm{P})=33$ and $\left.15 \mathrm{~Hz}, \mathrm{P}^{\mathrm{A}}\right) ;{ }^{13} \mathrm{C}\left\{{ }^{1} \mathrm{H}\right\} \mathrm{NMR}\left(300 \mathrm{MHz}, \mathrm{C}_{6} \mathrm{D}_{6}, 25^{\circ} \mathrm{C}\right) \delta=$

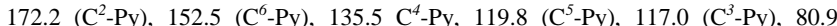
$\left(\mathrm{OCH}_{2}-\mathrm{Py}\right)$; elemental analysis calcd $(\%)$ for $\mathrm{C}_{51} \mathrm{H}_{48} \mathrm{BNOP}_{3} \mathrm{Rh}$ : C $68.25, \mathrm{H} 5.39, \mathrm{~N}$ 1.56; found: C 68.15 , H $5.59, \mathrm{~N} 1.53$

\section{Acknowledgements}

The generous financial support from MICINN/FEDER (Project CTQ2008-03860) and G.A. (Gobierno de Aragón, Project: PM 036/2007) is gratefully recognized. Authors also thank Dr. S. Jiménez for preliminary observations. V.P. thanks C.S.I.C. for an I3P postdoctoral contract.

\section{Keywords: Tishchenko reaction $\bullet$ rhodium • esters $\bullet$} aldehydes $\bullet$ hydrido ligands

[1] T. Seki, T. Nakajo, M. Onaka, Chem. Lett. 2006, 35, 824-829.

[2] K. Ekoue-Kovi, C. Wolf, Chem. Eur. J. 2008, 14, 6302-6315.

[3] a) D. Milstein, Top. Catal. 2010, 53, 915-923 and references therein; b) J. Zhang, G. Leitus, Y. Ben-David, D. Milstein, J. Am. Chem. Soc. 2005, 127, 10840-10841.

[4] M. Haniti, S. A. Hamid, J. M. Slatford, J. Williams, Adv. Synth. Catal. 2007, $349,1555-1575$.
[5] M. M. Mojatahedi, E. Akbarzadeh, R. Sharifi, M. S. Abaee, Org. Lett. 2007, 9, 2791-2793.

[6] M. R. Crimmin, A. G. M. Barrett, M. S. Hill, P. A. Procopiou, Org. Lett. 2007, 9, 331-333.

[7] a) Y.-S. Hon, Y.-C. Wong, C.-P. Chang, C.-H. Hsieh, Tetrahedron, 2007, 63, 11325-11340; b) T. Ooi, K. Ohmatsu, K. Sasaki, T. Miura, K. Maruoka, Tetrahedron Lett. 2003, 44, 3191-3193; c) T. Ooi, T. Miura, K. Takaya, K. Maruoka, Tetrahedron Lett. 1999, 40, 7695-7698.

[8] a) R. M. Gauvin, T. Chenal, R. A. Hassan, A. Addad, A. Mortreux, J. Mol Catal. A: Chem. 2006, 257, 31-40; b) M. R. Bürgstein, H. Berberich, P. W. Roesky, Chem. Eur. J. 2001, 7, 3078-3085; c) H. Berberich, P. W. Roesky, Angew. Chem. 1998, 110, 1618-1620; Angew. Chem. Int. Ed. 1998, 37, 1569-1571; d) S. Onozawa, T. Sakakura, M. Tanaka, M. Shiro, Tetrahedron, 1996, 52, 4291-4302.

[9] T. Andrea, E. Barnea, M. S. Eisen, J. Am. Chem. Soc. 2008, 130, 2454-2455.

[10] A. Zuyls, P. M. Roesky, G. B. Deacon, K. Konstas, P. C. Junk, Eur. J. Inorg. Chem. 2008, 693-697.

[11] [Ru]: a) M.-O. Simon, S. Darses, Adv. Synth. Catal. 2010, 352, 305-308; b) S. Omura, T. Fukuyama, Y. Murakami, H. Okamoto, I. Ryu, Chem. Commun 2009, 6741-6743; c) S.-I. Murahashi, T. Naota, K. Ito, Y. Maeda, H. Taki, J. Org. Chem. 1987, 52, 4319-4327; d) T. Ito, H. Horino, Y. Koshiro, A Yamamoto, Bull. Chem. Soc. Jpn. 1982, 55, 504-512; e) H. Horino, T. Ito, A Yamamoto, Chem. Lett. 1978, 17-20; (e). [Os]: f) P. Barrio, M. A. Esteruelas, E. Oñate, Organometallics 2004, 23, 1340-1348. [Ir]: g) T. Suzuki, T. Yamada, T. Matsuo, K. Watanabe, T. Katoh, Synlett 2005, 9, 1450-1452; h) K. A. Bernard, J. D. Atwood, Organometallics 1988, 7, 235-236. [Ni]: i) S. Ogoshi, Y. Hoshimoto, M. Ohashi, Chem. Commun. 2010, 46, 3354-3356.

[12] R. Grigg, T. R. B. Mitchell, S. Sutthaivaiyakit, Tetrahedron 1981, 37, 4313-4319.

[13] M. Massoui, D. Beaupère, L. Nadjo, R. Uzan, J. Organomet. Chem. 1983 , $259,354-353$

[14] a) D. H. T. Phan, B. Kim, V. M. Dong, J. Am. Chem. Soc. 2009, 131, 15608-15609 and references therein; b) Z. Shen, H. A. Khan, V. M. Dong, $J$. Am. Chem. Soc. 2008, 130, 2916-2917; c) S. H. Bergens, D. P. Fairlie, B. Bosnich, Organometallics 1990, 9, 566-571.

[15] C. Tejel, M. A. Ciriano, S. Jiménez, V. Passarelli, J. A. López, Angew. Chem 2008, 120, 2123-2126; Angew. Chem. Int. Ed. 2008, 47, 2093-2096.

[16] S. Jiménez, J. A. López, M. A. Ciriano, C. Tejel, A. Martínez, R. A. SánchezDelgado, Organometallics, 2009, 28, 3192-3202.

[17] S. Jiménez, Ph D Thesis, Univ. Zaragoza, 2008

[18] Hydrogen was detected by a signal at $\delta=4.45 \mathrm{ppm}$ in the ${ }^{1} \mathrm{H}$ NMR spectrum in $\mathrm{C}_{6} \mathrm{D}_{6}$. In the same line, reaction of $p$-methoxybenzaldehyde with $\mathbf{1}$ in a $4: 1$ molar ratio at r.t. showed the initial evolution of hydrogen, followed by the formation of $p$-methoxybenzene and complex 2 in a 1:1 molar ratio as the sole products from aldehyde decarbonylation.

[19] In these cases, the catalysis was accompanied with the formation of $\left[\left(\mathrm{PhBP}_{3}\right) \mathrm{Rh}(\mathrm{H})_{2}(\mathrm{CO})\right](2)$ and $p$-methoxybenzene/toluene as products coming from the decarbonylation process commented above.

[20] T. Seki, K. Akutsu, H. Hattori, H. Chem. Commun. 2001, 1000-1001.

[21] a) C. Krug, J. F. Hartwig,. Organometallics 2004, 23, 4594-4607; b) C. Krug, J. F. Hartwig,. J. Am. Chem. Soc. 2002, 124, 1674-1679.

[22] a) M. C. Willis, Angew. Chem. 2010, 122, 6162-6164; Angew. Chem. Int. Ed. 2010, 49, 6026-6027 and references therein; b) Z. Shen, P. K. Dornan, H. A. Khan, T. K. Woo, V. M. Dong, J. Am. Chem. Soc. 2009, 131, 1077-1091; c) M. Beller, J. Seayad, A. Tillack, H. Jiao, Angew. Chem. 2004, 116, 3448-3479; Angew. Chem. Int. Ed. 2004, 43, 3368-3398.

Received: ((will be filled in by the editorial staff))

Revised: ((will be filled in by the editorial staff)) Published online: ((will be filled in by the editorial staff)) 
Entry for the Table of Contents

Catch Phrase

Cristina Tejel, * Miguel A. Ciriano, and Vincenzo Passarelli.............. Page - Page

Rhodium(III)-Catalyzed Dimerization of Aldehydes to Esters
No sooner said than done. A rhodium(III) hydride complex is an outstandingly effective and selective catalyst for the dimerization of aldehydes to the corresponding esters. Evidences for an unusual mechanism in catalysis by rhodium are given. 